\title{
Listen Up! Be Responsible! What Graduate Students Hear About University Teaching, Graduate Education and Employment
}

\author{
Erin Aspenlieder \\ University of Guelph \\ Marie Vander Kloet \\ McMaster University
}

\begin{abstract}
What we hear at universities and in public conversations is that there is a crisis in graduate student education and employment. We are interested here in the (re)circulation of the discourses of crisis and responsibility. What do graduate students hear about their education, their career prospects, and their responsibilities? How does work in educational development contribute to these conversations? We explore these questions through an analysis of two data sets: the course outlines for multidiscipline graduate courses on university teaching, and popular and academic press articles on graduate education and employment. Through this discursive analysis, we first examine what graduate students hear through these two archives of writing. We then unpack two key discourses that emerge across the archives: the privileging of practice over theory, and the desire to assign responsibility for how the crisis of graduate education and employment should be resolved and by whom.
\end{abstract}

\section{Résumé}

Ce que l'on entend dans les universités et en public, c'est que l'emploi et la formation universitaire aux cycles supérieurs sont en pleine crise. Nous nous intéressons à la (re)circulation des discours sur la crise et la responsabilité. Qu'est-ce que les étudiants des cycles supérieurs entendent au sujet de leur formation, de leurs perspectives de carrière et de leurs responsabilités? Comment est-ce que le travail en développement éducationnel contribue à ces conversations? Nous explorons ces questions par le truchement d'une 
analyse de deux groupes de données : des plans des cours multidisciplinaires de cycles supérieurs portant sur l'enseignement universitaire et des articles de presse populaires et universitaires portant sur la formation aux cycles supérieurs et sur l'emploi. Dans cette analyse discursive, nous examinons d'abord ce que les étudiants des cycles supérieurs saisissent en lisant ces deux types d'archives écrites. Nous déconstruisons par la suite deux discours essentiels qui ressortent de ces archives, soit de privilégier la pratique plutôt que la théorie, et d'attribuer à quelqu'un la tâche de résoudre la crise de l'emploi et de la formation universitaire aux cycles supérieurs.

\section{Voices in the Conversation}

I had expected, like I am sure a number of PhDs do, to go into an academic teaching and research position. However, I realized very quickly that this would be hard going to achieve. At the same time I realized that when I looked at my $\mathrm{PhD}$ as a whole I had a number of transferable skills. (Polk, 2014b, para. 1)

I had always imagined I'd be a professor. It never occurred to me that I would do anything other than teach history. But, I graduated in 2009, one of the worst years to enter the academic job market. After three years applying for tenure track jobs and post-docs, I decided to end my quest for academic employment and find others ways to contribute to society. (Polk, 2014a, para. 1)

These statements from former graduate students echo what we hear at our universities and in public conversations: There is a crisis in graduate student education and employment in academic positions. We are interested here in the (re)circulation of the discourses of crisis and responsibility. What do graduate students hear about their education, their career prospects, and their responsibilities? How does work in educational development contribute to these conversations? We explore these questions through an analysis of two data sets: the course outlines, or syllabuses, for graduate courses on university teaching; and articles in the popular and academic media on graduate education and employment. Through this analysis, we examine the discrepancies between the messages graduate students hear from the two sources. ${ }^{1}$ We take note of how such courses prepare graduate students for academic careers as if this is a de facto outcome of graduate studies. In contrast, the articles describe a mismatch between graduate students' academic preparation and their employment outcomes. Our analysis follows discussions of methods and of themes in the data.

This gap between what graduate students hear from the courses and what they hear in the articles is especially worthy of consideration given the public, administrative, and governmental interest in exploring and closing it. One of the oft-cited starting points for this conversation is the 2008 Canadian Association of Graduate Studies (CAGS) Report on Professional Skills Development for Graduate Students, in which the national organization outlines the university's "responsib[ility] for providing graduate students with the best possible preparation for their future roles whether within academia or in other sectors" (p. 4). As the university community grapples with the purpose of graduate degrees, the question implicitly circulating is what skills and knowledge graduate studies should provide if education is to align with the demands of the "other sectors" in which degree holders might be employed. 
Indeed, the public discussion of the value of graduate education often appears in the context of a "crisis" in employment (Charbonneau, 2011c; Newhouse, 1999; Tamburri, 2010). Census data indicate that while the number of university professors has more than doubled in the last three decades, the number of full-time positions has declined, and the number of these positions held by persons under 35 has dropped dramatically (Desjardins, 2012, p. 7). Yet more than two thirds of graduates from Ontario doctoral programs pursued a doctorate with the intention of becoming university professors (Desjardins, 2012, p. 20). What these statistics indicate is a mismatch between the interests of those pursuing graduate studies and the availability of these forms of work in the academy.

We are not bystanders at the crisis of graduate education or the discursive formations of good practice in university teaching, as represented in the course syllabuses. As educational developers, ${ }^{2}$ researchers, teachers and former graduate students who did not assume tenure-track jobs, we are called upon, in various contexts, to speak to these questions with different voices. We both teach courses discussed in this paper; similarly, we read and discuss, both informally and publicly, the popular writing about graduate education. We are authors and audience for these discourses. It is often a position of discomfort. We question how we can approach our work, given our attention to the competing discourses examined here. Elsewhere, we have considered our own experience through auto-ethnographic methods, and our writing and analytical practice for this paper draws on our previous approach to critical, reflective, and qualitative analyses in the scholarship of teaching and learning (Vander Kloet \& Aspenlieder, 2013).

\section{Methodology}

In this paper, we analyze two data sets: outlines of graduate courses on university teaching offered through or in conjunction with teaching and learning centres at Canadian institutions; and media articles focused on the crisis in graduate education and employment. We look at these two types of texts together, because each shapes and contributes to graduate education and employment and the burden of responsibility for professional development. As we explore what graduate students hear about their educations and their prospects for academic work, these data offer us an opportunity to consider the resonances and dissonances between the two bodies of writing.

We undertake this work through discourse analysis. ${ }^{3}$ That is, we undertake analysis that is concerned with what is said and how it is said, rather than with the frequency with which it is said. Interdisciplinary methodologies in the scholarship of teaching and learning allow for a rich panoply of research, but the hierarchy that continues to privilege quantitative methodologies discourages analyses of text and discourse. Moreover, qualitative methodologies in teaching and learning must allow for methods focused on textual analysis in addition to methods through which human participants' voices are heard and privileged. While researchers of studies such as ours need to provide clear statements of methodology, it is likewise important that we resist the call to justify our methodology as worthy or valid.

Analyses of discourse seek to understand how a particular truth is established and "to discover the support mechanisms that allow it to be said and keep it in place" (Mills, 2004, p. 45). Here, we examine syllabuses and articles to consider what truths are told or what a graduate student hears about university teaching. Using archaeological meth- 
ods typical of discursive analysis, we began by tracing a "description of regular patterns within a discourse" (Mills, 2003, p. 24). We observed recurring themes of responsibility, employability, and a practice-theory dichotomy in the texts we analyzed. This archaeological reading allowed us to note what constitutes particular archives (course outlines and media articles) before we undertook genealogical methods concerned with the operations of power in discourse (Kendall \& Wickham, 1999; Tamboukou \& Ball, 2003). As a result, some of our analysis is focused on description of the contents of each archive.

Genealogical analysis "can be understood as a gradual untangling of discourse and a close attention to the processes which shape what counts as truth and desirable ways of being" (Vander Kloet, 2010, p. 55). Our genealogical inquiry focuses on how, within these archives, particular truths about graduate education are told and, in turn, what practices will come to be understood as responsible.

Our choice of texts is an integral component of our methodology. Diverse audiences read course syllabuses; their content is intended to convey the ideas, skills, and values of the courses themselves. By employing discourse analysis, we can highlight the ways instructors write about the courses they teach, but we cannot engage with the perceptions of course instructors and students about how these courses are implemented and experienced. Knowing this, we focus on what the syllabuses say, to the exclusion of what instructors and students might subsequently say, precisely because of the public, communicative function of syllabuses. Like the syllabuses, the media articles speak to a broad audience. As with the syllabuses, we cannot ascertain how precisely various audiences respond to the articles, nor was this our analytical focus. Instead, we examine how this writing collectively contributes to the discursive shaping of a crisis in graduate education and what can be understood from examining these texts together.

\section{Course Outlines}

There is a proliferation of courses on education in Canada. For this paper, we did not include discipline-specific education courses, educational research courses undertaken in education faculties, or courses that are part of pre-service teacher accreditation. Rather, we attended to courses focused on university teaching offered through teaching and learning centres either distinct from or in conjunction with graduate studies, continuing education, or related faculties. We included courses with certain qualities: courses offering graduate credits; noncredit courses, with or without transcript notation; courses open to students from multiple disciplines; courses including multi-week participation in class with peers/instructors (or blended/online format); and courses with assessments to be completed outside of class.

We identified Canadian institutions with graduate-degree-granting programs that offered courses meeting the criteria above. Courses were located by reviewing online university course calendars, university teaching and learning centre websites, graduate studies websites, and university websites. From this search, we identified 22 institutions and found course outlines online or requested them by email. Occasionally, staff members emailed or phoned us to ask follow-up questions about the research or to clarify what was being requested. ${ }^{4}$ Of the 22 institutions contacted, 19 institutions shared their materials, and as a result, we collected 23 course outlines for 2012-2014* and included them in this research (*All course syllabuses listed are for the years 2012-2014, with the exception of one from 2009. The 2009 syllabus was described as "current" by the institution). 


\section{Popular and Academic Media Articles}

To determine which articles to include, we aimed to compile a collection of sources that graduate students themselves might have encountered. To this end, we selected from the popular media the Globe and Mail, Maclean's magazine, and the Toronto Star, because these outlets have national scope, distribution, and readership. From the academic media, we chose University Affairs and its hosted blogs because of its national audience and wide readership.

Within these four sources, we set search parameters by using specific keywords ${ }^{5}$ to search for relevant articles. We then read the articles with the aim of identifying writing that engaged with our focus on the expansion of graduate enrollment, sessional teaching (in contrast to permanent work) and professional development. These articles referred to others, including some in American sources, and we read a number of these. The total search yielded 48 articles. We disqualified seven articles for focusing exclusively on sessional instructors or contract labour to the exclusion of graduate students. This method resulted in a set of 41 texts from nine sources, mostly from 2009 to 2013, that, taken together, represent the wider national conversation.

\section{The Archives: Course Outlines and Media Articles}

We now turn to the archaeological work of describing the texts under analysis. This descriptive work is a key aspect of discourse analysis in that it synthesizes the data so that readers can navigate the analysis that follows.

\section{Graduate Courses on University Teaching}

Graduate courses on university teaching bear remarkable similarity to one another in organization, outcomes, and assessments. We included syllabuses from Canadian institutions of varying sizes and mandates, but the differences among them are minimal. Here, we outline shared and unique characteristics of the stated curriculum, as described in the course outlines.

Organization. Courses are most often one semester long. Occasionally, courses may be distributed over two semesters or may run for slightly less than a full semester (e.g., for six weeks for full days). Courses are often housed within an education faculty, a continuing education program, or a teaching and learning centre. Teaching and learning centre staff or faculty members from other parts of the institution (most commonly from education and psychology departments) typically instruct the courses. Courses are nearly all characterized as pass/fail; some exceptions include those from education faculties, which are normally graded.

The courses are usually open to graduate students; some are open to post-doctoral fellows or, very rarely, to instructors. Approximately one third of the courses are embedded in broader programming at a teaching and learning centre (e.g., certificate programs). Although prerequisites or antirequisites are rare, they are present at institutions that offer multiple courses.

Outcomes. All syllabuses include learning outcomes. Most are expressed as a series of statements; rarely, outcomes are set out as a narrative. Outcomes are frequently tagged in relation to assessments: Either assessments are explicitly mentioned in the out- 
come statements, or outcomes are given numbers and distributed across assessments and weekly course plans.

The language and structure of outcomes also follow patterns. First, outcomes include an action verb in reference to a practice or line of thinking. Second, outcomes reference a small cluster of skills or capacities. Many outcomes were like these statements:

- Demonstrate understanding of and evaluate research on teaching/learning and integrate into practice (e.g., teaching techniques, syllabus design)

- Reflect on teaching or produce teaching philosophy

- Understand and apply research on learning, adult education, or learning styles

- Understand, apply, and practise teaching techniques

- Implement active learning

- Provide student and peer feedback

- Select or design appropriate or aligned assessments

- Foster inclusive, accessible, or diverse classrooms

- Assess and incorporate teaching technologies

- Develop teaching confidence

Two course outlines we analyzed departed from the pattern of textual representation of learning outcomes. The syllabus for Dalhousie CNLT5000/5001 (see Appendix for information on the documents analyzed) includes outcomes focused on demonstration and integration of understanding of "social and institutional factors that influence teaching." At the University of Windsor, an outcome of course 05-80-502 is to evaluate "educational theories and approaches, particularly as they relate to the cultural, political and institutional contexts of higher education." These departures reveal a disruption in the pattern of learning outcomes, which are otherwise focused on the development of teaching skills, the use of research for practice, the impetus toward introspective reflection, and the theory of constructive alignment.

Assessments. Course assessments, like organization and outcomes, tend to be uniform. Most courses require a course portfolio ${ }^{6}$ a teaching philosophy, participation or attendance in class sessions, and the delivery of a short lesson. ${ }^{7}$ For many assessments, it is common for students to submit multiple drafts. Most often these requirements constitute the entirety of how students would be assessed. However, other types of assessment are found in several courses, including writing self-assessments and reflective papers, creating a teaching dossier, participating in a blog or online discussion board, undertaking peer or mentor teaching observations, and writing research responses or annotations.

The outcomes and assessments emphasize the skills and knowledge of the "good" teacher: crafting learning outcomes, designing assessments, teaching learner-centred classes, and engaging in self-reflection (see Nicoll \& Harrison, 2003). In attending to these important skills and this knowledge, the stated curriculum of the courses rarely addresses the institution and/or higher education as a whole. In this way, the course outlines isolate university teaching from the context in which graduate students may work; this gap in the stated curriculum is troubling given the representation of a crisis in graduate education and employment reflected in our other data set, the media articles. 


\section{Popular and Academic Media: Higher Education in "Crisis"}

The articles we read describe a crisis in graduate education. As it is represented, the crisis stems from an incongruity between the demands for graduate degree holders in the knowledge economy and how these degree holders are trained and produced as future professors.

According to the Organisation for Economic Co-operation and Development (OECD), "Knowledge is now recognised as the driver of productivity and economic growth, leading to a new focus on the role of information, technology and learning in economic performance" (1996, para. 1). One of the principal markers of a developed and growing knowledge economy is the number of persons with PhDs a nation both produces and has access to. Canada's federal and provincial governments continue to push for an increase in $\mathrm{PhD}$ graduates because "despite an increased production of PhDs in the past 20 years ... we still fell from 2oth to 23rd spot among OECD countries in the number of $\mathrm{PhD}$ graduates per capita during that time"; without growth in their numbers, Canada will continue to lag (Charbonneau, 2011d, para. 4).

While governments continue to demand an increased number of graduate degree holders for positions in the expanding knowledge economy, graduate education continues to function largely as preparation for a career among the professoriate. This vision of graduate school can be thought of as a replication model, with students trained as if they will assume academic positions, replicating their instructors (Rose, 2012, p.7).

Within the articles, this replication model is castigated for simultaneously misleading graduate students about the likelihood of securing tenure-track jobs and inadequately preparing them for the more likely employment outcome of a nonacademic position. The articles cacophonously declare the decline in tenure-track positions and the concomitant need for graduate students to (re)imagine a different purpose and outcome for their education (assuming that the initial purpose was to contribute to the academic community and the outcome was to permanently join its ranks as faculty):

- "More people graduate with PhDs, but full-time tenure track positions are harder to get. Many highly educated Canadians struggle to find adequate-paying work that meets their credentials." (Tremonti, 2014, para. 4)

- "The situation is grim, I’ve taken to using the word 'dire."” (Gillis, 2013, para. 4)

- "The job crisis for faculty jobs-especially for new Ph.D.'s looking for tenure-track jobs-is spreading." (Jaschik, 2010, para. 1)

- "More of these grads now struggle to find employment that matches the level and nature of their education-particularly employment in universities as tenure-track faculty." (Fullick, 2013b, para. 1)

- "Many of the students who enter graduate programs with the aim of an academic job at the end will never even graduate: Over half of students in the humanities and 40 per cent of those in the social sciences do not complete the degree. Who's willing to gamble on those kinds of odds?” (Chiose, 2013, para. 5)

- "The market sucks. Now you know." (Rybak, 2009, para.1)

Taken together, the descriptions of the crisis assume a quasi-hysterical tenor, as they threaten not simply the denial of the tenure track but the absence of meaningful work at all. ${ }^{8}$

In their descriptions of crisis, the course outlines and articles deliver conflicting messages. In what follows, we work through these messages with the aim of exploring the discourses of crisis and responsibility that accompany these texts. 


\section{Across the Texts: Privileging Practice, Requiring Responsibility}

In analyzing the course outlines and the media articles, we see how particular truths emerge across texts. Moreover, we also note tensions, because no single discourse emerges. Rather, what we see is a tangled collection of claims about university teaching and the crisis of graduate education and employment. We focus specifically on two areas in which both bodies of writing contribute: the privileging of practice over theory, and the impetus to take up responsibility.

We focus on these two themes in particular because the concept of responsibility dominates the articles, in calls to graduate students to proactively and individually earn employment. One of the ways in which the articles argue for graduate students to differentiate themselves and earn employment is through broadened professional development, including teaching. Considering this call alongside the dominant theme in the course outlines-a theory-practice divide-suggests how the courses in "separating out the 'how' from the 'why' and 'what' of higher education [allow] questions about the meanings and purposes of education to be marginalised" (Nicoll \& Harrison, 2003, p. 30). In what follows we explore how these two themes intersect and complicate each other.

\section{Privileging Practice}

No theory please, we're practitioners. Within the course outlines, we see a pervasive privileging of practice over theory. Theory is, at best, only a means by which one gets to the important work of describing and undertaking one's practice as a teacher. Syllabuses routinely emphasize practice over theory by stating that a course "is intended to be practical" (Wilfrid Laurier University) and by assuring students that "skills developed through participation in this seminar series are directly transferable" (Ryerson University CILT 105). Others may explicitly focus on "teaching practice as opposed to theory" (University of New Brunswick). At most, some syllabuses describe an openness to "integrat[ing] theory and practice" (University of Calgary) or say that a course might be "designed to balance theory and practice" (Queen's University SGS901).

The focus on practice over theory is also evidenced in the descriptions of course assessments and outcomes. Assessments are most often the creation of teaching materials that offer concrete application (e.g., course outlines, planned lessons); outcomes typically point to either teaching skills or the development of concrete materials. While the assessments and outcomes gesture to integrating research (framed as theory), other forms of engagement with theory, such as reflection, are cursory. Further, reflective writing assignments structure engagement with theory as an inwardly gazing experience, with students reflecting on and rationalizing their choices with regard to teaching philosophies or course designs.

The impetus toward the practical over the theoretical suggests that these courses seek to develop the concrete, professional skills endorsed in the articles. Interestingly, these courses are directed toward students who want to teach in the academy, and as such, they do not open up previously unavailable career paths (as other professional development opportunities might). Further, these courses may be the precise place where the development of pedagogical skills offers hope for the possibility and probability of obtaining faculty positions. In one article we analyzed, a PhD student expresses his belief that "the academic job market is experiencing a 'temporary low' and will soon turn around. 'If 
teaching is your main goal and you are willing to wait it out, as long as you keep up a heavy research agenda and publish as much as possible, then finding a job is just a matter of time" (Tamburri, 2010, para. 31). With the belief that if one works hard, one will achieve an academic position still strongly held, it is unsurprising that graduate courses on university teaching find receptive audiences eager to demarcate themselves as exceptional and deserving. Moreover, the dearth of academic positions coupled with their continued desirability leaves fertile ground for the neo-liberal rhetoric of individualism, responsibility, and self-governance to flourish.

Good practitioners? Educational developers and the promise of professional development. As educational developers, we find that our examination of the course outlines and the media articles risks prompting some challenging questions about our conduct and/or positions. Rather than asking the questions we might typically ask about our services, ${ }^{9}$ we posit that it is necessary to ask questions such as these: How do the course outlines reproduce or establish particular discursive truths about graduate professional or pedagogical development and employability? How do the courses work to secure our own position as deserving and necessary workers in the academy?

The field of educational development, through the offering of courses, participates in broader discussions of professional development for graduate students. The courses, although primarily focused on developing pedagogical skills applicable within the academy, benefit from the crisis of graduate education and employability. Graduate students seeking to differentiate themselves in the labour market sustain the popularity and need for the courses. Further, by offering courses that privilege practice over theory, we assert the perceived need for practical and concrete teaching skills rather than sustained engagement with theory, including analyses of the economic, social, cultural, and political forces that shape how it is possible for graduate students to teach. ${ }^{10}$

The course syllabuses, through their focus on practical pedagogical skill development, also shape how we come to understand the instructors of these courses. As providers of sought-after practical and marketable skills, educational developers may be read as integral to both graduate education, with its newly identified focus on professional development, and the academy, which increasingly demands flexible workers whose roles are congruent with supporting the neo-liberal turn in higher education (see, for example, Bansel, 2007; Bansel \& Davies, 2005; Davies \& Bansel, 2010; Giroux, 2012; Saunders, 2010). But the positioning of university teaching as a collection of practical skills may inadvertently entrench beliefs about teaching that educational development seeks to redress: namely, its devaluation. Melonie Fullick, a graduate student, blogger, and researcher in higher education, notes that "we are already operating in a professional context where graduate students are often encouraged to treat teaching primarily as something required to win and keep an academic position" (2012a, para. 7). By electing not to participate in discussions about the meaning and value of teaching and instead tailoring our contribution to that of practical skills development, we risk re-establishing the belief that teaching is inherently practical rather than intellectual work. Fullick observes that "pedagogical knowledge tends to be dismissed, either implicitly or explicitly, as less valuable knowledge; teaching work can be fragmented and outsourced" (2012a, para. 7). Rather than redress the secondary role teaching is presumed to have played in the academy, a turn to practical skill development may entrench hierarchies of research over teaching. 


\section{Being Responsible}

A focus on practice over theory, seen throughout the course outlines and the articles, emphasizes the need for responsibility: specifically, one's capacity to bear responsibility for one's successes and failures in relation to graduate education and employability. In this regard, pedagogical and professional skills development promises marketability to those who take it up. Graduate students (and their educational developer counterparts) who embark on individual initiatives to develop professionally can come to be read as "good subjects" - those who embody responsibility. In many ways, taking on professional development as a graduate student might appear to be one way to avoid being impacted by the crisis. Certainly, as educational developers, we must ask whether graduate courses on university teaching are offered as a possible inoculation against theory-heavy, research-focused graduate education that is framed as fraught in the discourse of the crisis of graduate education. Moreover, we must more closely examine the meaning of being invited, coerced, or tempted to become responsible members of the academy by questioning what this expectation secures and what it forecloses.

The individual or the institution in crisis? The articles both describe the crisis in graduate student education and employment and assign responsibility for addressing it. They split responsibility between the individual graduate student and the institution as a whole. While we examine here the discursive arguments for both assignments of responsibility, we aim to open the discussion beyond attributing blame to begin asking questions about the purpose of higher education itself. We want to pose these broader questions in part because keeping attention on who is responsible, how to make those responsible take action, and how such actions will make the crisis disappear distracts us-the university community and the public-from recognizing changes in the structure and function of Canadian universities. Focusing on responsibility presents the chimera that the crisis can be addressed with the prescription of a program or a more productive graduate student, which belies the fact that neither a professional development program nor a more productive student will address the reorganization of the university.

Individual responsibility. Rosanna Tamburri points out that, for a job, "a $\mathrm{PhD}$ is necessary but not sufficient. To be really marketable, students also need to know how to communicate effectively and how to network. They need to show creativity and leadership and possess other so-called soft skills, which universities are trying to foster through professional development programs" (2013b, para. 8). By imagining these skills as those that will ensure students are "really marketable," students themselves assume accountability for either already possessing these skills or attending the programs that will provide them.

This notion of accountability follows from the neoliberal model of higher education in which "success or failure is attributed to the individual's ability or inability to utilize the opportunities available" (Maistry, 2012, p. 520). Several outcomes follow from this idea of individual responsibility for success, not the least of which are the personal, mental, emotional, and financial stresses that accompany both the attempts to achieve all the markers of merit and worth and the likelihood that with such a narrow understanding of success it is easier to feel like a "failure" (Fullick, 2011, para. 8).

Also attending this idea of the individual student as responsible for success is the promise that if students do avail themselves of all the professional development programs 
and do acquire sufficient skills, they will be protected against the crisis of an academic labour market flooded with would-be professors. In this way, the course outlines come to promote a fallacy: graduate students take a course with the expectation that by participating in this professional development opportunity they are making themselves more "marketable," while the course itself largely ignores the realities of the market they are preoccupied with entering.

The course outlines do gesture toward the academic employment market in one aspect: the requirement that students provide a teaching dossier and a teaching philosophy. While some syllabuses described these documents as exercises in reflective practice, the demand for the teaching dossier and philosophy in the academic job market also suggests the way these assessments could be viewed-within the course and by the students- as tools for distinguishing their job applications and for marketing themselves.

Rather than looking at the academic teaching market directly, these course outlines operate as bulwarks against addressing the legitimate crisis in employment and the likelihood that the student will not be a tenure-track professor. The institution, even if it is "held accountable" by providing "statistics of labour market outcomes and career pathways" (Chiose, 2013, para. 2), can redirect its responsibility by pointing individual students to the suite of programs and resources that promise to prepare them for the market. In this way any notion of "responsibility" of the institution is foisted on the students, who will either succeed or fail, presumably on the basis of their individual effort and worth.

Institutional responsibility. In considering institutional responsibility to respond to the crisis, the articles typically argue for some combination of reforms: altering the number of graduate students admitted to programs (Chiose, 2013); differentiation of PhD programs at specific institutions (Tamburri, 2014); reimagining the dissertation as a form to make it more applicable in nonacademic settings (Tamburri, 2013a); and more widely publicizing time-to-completion and employment data. The presentation of these reforms may come about in explicit attributions of responsibility: "The academy-your mentorsare to blame" (Charbonneau, 2011d, para. 8). Or it may appear in more oblique questioning of the motivations of the replication model of graduate education: "Really, all we train people for is to be another Mini-Me," says Carolyn Watters, president of the CAGS. "As faculty members we should be more sensitive to the fact that not everybody is going to be like us" (Tamburri, 2010, para. 6).

Taylor (2011) sees the motivation for replication training not simply as historical continuity, but as a nefarious move on the part of the university to secure cheap labour without consideration for the graduate students themselves: "The academic job market collapsed in the 1970s, yet universities have not adjusted their admissions policies, because they need graduate students to work in laboratories and as teaching assistants. But once those students finish their education, there are no academic jobs for them" (para. 2). Taylor's criticism may appear as common sense: Graduate school should be about more than training for the professoriate. But calls for more, better, or different "professional skills development" indict the institution without asking broader questions about the university and labour markets.

\section{Conclusion: Limitations and Beyond Blame}

By looking at two data sources, syllabuses for graduate courses in university teaching alongside media articles on graduate education and employment, we have argued that 
there is an incongruity in what graduate students may hear in discourses of responsibility, employability, and higher education. We see an opportunity in this incongruity to begin asking broader questions not just about how this crisis came about (Fullick, 2014) but also about what we imagine and hope for in the university in the future.

If we can shift past, or through, responsibility, we arrive at questions about the goals of graduate education with regard to academic careers, nonacademic careers, satisfaction of intellectual curiosity, deepened awareness of a discipline, and privileged opportunities for scholarly exploration. We begin to think about what we all want from higher education as workers, citizens, and lifelong learners. These are questions that we need to ask ourselves as educational developers and that we need to ask of our graduate students.

In asking our current set of questions for this study, we encountered limitations. Our methodological approach of discourse analysis limited our consideration of the graduate courses to their course outlines and did not allow for a thorough exploration of the context or delivery of courses. We anticipate that research into the expectations and experiences of students and instructors in such courses would yield new and important results. While we are confident of the merit in this study of reading the two data sets together, a further study focused exclusively on the popular or public representation of teaching in higher education could reveal further nuances outside the scope of this publication.

Within this paper, we contribute to a broadening of the discourse around higher education in ways that open space to think about the organization and funding of the institution. As long as we remain focused on assigning responsibility, we foreclose the possibility of asking different questions. We risk seeking solutions for a crisis in employment while failing to simultaneously query the value, function, and meaning of the institution itself.

\section{Notes}

1. We do not claim that all graduate students "hear" all course outlines or media articles. Rather, we argue that graduate students are directly and indirectly embedded in, and shaped by, the discourses of higher education that circulate in these texts.

2. Educational developers, known also as "educational consultants" or "academic developers," provide expertise for the enhancement of teaching and learning at colleges and universities.

3. In undertaking discourse analysis, the question of what is discourse arises. Foucault and scholars who employ his methods inform our work. Davies (2000) and Mills (2004) posit that discourses define and organize what counts as truth, competing with and discounting alternate discourses. Discourse can also be described as "a clustering of statements or patterns of what is considered to be knowable" (Vander Kloet, 2010, p. 61).

4. We note that these conversations were valuable to the analytical process, not simply a procedural step in our methodology. The questions and comments encouraged critical discussions and writing characteristic of our auto-ethnographic method as well as consideration of the direction of our current and future research.

5. These were our keywords: higher education (popular media sources), graduate students, graduate student employment, sessional and contract instruction, graduate programs, professional and academic skills.

6. The course portfolio commonly includes learning outcomes, a syllabus, assessments or rubrics, and learning or teaching techniques. More rarely, it includes concept maps, policies, and selected content or readings. 
7. These are often an iteration of the instructional skills workshop (ISW) model of teaching short mini-lessons to a group of peers and receiving peer feedback in a structured pattern (written and oral feedback with set timelines for teaching and provision of feedback). The ISW model has participants teaching multiple mini- lessons over the course of a few days.

8. While the specificity of the rhetoric and representation of crisis in the humanities is outside the scope of this paper, the discourses of responsibility and employability apply across disciplines. The job numbers for tenured positions reveal a parallel incongruity between $\mathrm{PhD}$ training for academic positions and employment in nonacademic careers among all disciplines. That said, the crisis is not represented as equally dire across all disciplines. Academic positions in the humanities are described as scarce to non-existent, with statistics to support this representation (see Donoghue, 2010, and Desjardins, 2012). Further investigation into the differences among these representations would be a welcome addition to the research literature.

9. These are examples of typical questions we ask about our programming: What is the efficacy or the impact of our programming and how can we assess it? How can programs be continuously improved? What outcomes does this program achieve?

10. For analysis of how such courses do similar work at the faculty level, see Nicoll \& Harrison, 2003.

\section{References}

References marked with an asterisk indicate media articles analyzed for this paper.

Bansel, P. (2007). Subjects of choice and lifelong learning. International Journal of Qualitative Studies in Education, 20(3), 283-300.

Bansel, P., \& Davies, B. (2005). The time of their lives? Academic workers in neoliberal time(s). Health Sociology Review, 12(1), 47-58.

*Benton, T. (2009, January 30). Graduate school in the humanities: Just don't go. The Chronicle of Higher Education. Retrieved from http://chronicle.com/article/GraduateSchool-in-the/44846

*Bessette, L. (2013, May 20). One of 500. Inside Higher Ed. Retrieved from http:// www.insidehighered.com/blogs/college-ready-writing/one-500

*Blouw, M. (2013a, September 3). Universities should educate-employers should train. The Globe and Mail. Retrieved from http://www.theglobeandmail.com/globedebate/universities-should-educate-employers-should-train/article14078938/

*Bradshaw, J. (2013b, September 4). For a new kind of professor, teaching comes first. The Globe and Mail. Retrieved from http://www.theglobeandmail.com/news/national/ education/new-breed-of-university-faculty-puts-focus-on-teaching-over-research/ article14117866/

*Branswell, H. (2013, October 10). One in six newly graduate medical specialists can’t find work: report. The Globe and Mail. Retrieved from http://www.theglobeandmail. com/news/national/one-in-six-newly-graduated-medical-specialists-cant-find-workreport/article14794764/ 
*Brown, L. (2011, June 7). Ontario to fund 6,000 more masters and PhDs. The Toronto Star. Retrieved from http://www.thestar.com/life/parent/2011/06/o7/ontario_to_ fund_600o_more_masters_and_phds.html

Canadian Association of Graduate Studies. (2008). Professional skills development for graduate students. Ottawa, ON. Retrieved from http://www.cags.ca/documents/ publications/working/Prof\%20Skills\%20Dev\%20for\%20Grad\%20Stud\%20\%20 Final\%2008\%2011\%2005.pdf

${ }^{*}$ Carr, G. (2012, October 26). Graduate students need preparation for life outside university. The Globe and Mail. Retrieved from http://www.theglobeandmail.com/ news/national/graduate-students-need-preparation-for-life-outside-university/ article4699319/

${ }^{*}$ Charbonneau, L. (2010, January 11). Producing more PhDs. University Affairs. Retrieved from http://www.universityaffairs.ca/margin-notes/producing-more-phds/

${ }^{*}$ Charbonneau, L. (2011a, April 28). Is the PhD broken? University Affairs. Retrieved from http://www.universityaffairs.ca/margin-notes/is-the-phd-broken/

${ }^{*}$ Charbonneau, L. (2011b, November 16). Sessional instructors, the freelancers of higher ed. University Affairs. Retrieved from http://www.universityaffairs.ca/marginnotes/sessional-instructors-the-freelancers-of-higher-ed/

${ }^{*}$ Charbonneau, L. (2011c, November 30). Is Canada producing too many Phds? Yes, no and maybe. University Affairs. Retrieved from http://www.universityaffairs.ca/iscanada-producing-too-many-phds.aspx

${ }^{*}$ Charbonneau, L. (2011d, November 30). The problem with $\mathrm{PhD}$ training in Canada. University Affairs. Retrieved from http://www.universityaffairs.ca/margin-notes/theproblem-with-phd-training-in-canada/

${ }^{*}$ Chiose, S. (2013, April 30). PhD numbers have doubled but few graduates will find teaching jobs. The Globe and Mail. Retrieved from http://www.theglobeandmail.com/ news/national/education/phd-numbers-have-doubled-but-few-graduates-will-findteaching-jobs-ontario-study-finds/article11643817/

Davies, B. (2000). A body of writing 1990-1999. Walnut Creek, CA: Altamira Press.

Davies, B., \& Bansel, P. (2010). Governmentality and academic work: Shaping the hearts and minds of academic workers. Journal of Curriculum Theorizing, 26(3), 5-20.

Desjardins, L. (2012). Profile and labour market outcomes of doctoral graduates from Ontario universities. Ottawa, ON: Statistics Canada, Tourism and Centre for Education Statistics Division.

*Donoghue, F. (2010, September 5). Can the humanities survive the 21st century? The Chronicle of Higher Education. Retrieved from http://chronicle.com/article/Can-theHumanities-Survive-the/124222/

*Donoghue, F. (2011, November 1). Just don't go, the sequel? The Chronicle of Higher Education. Retrieved from http://chronicle.com/blogs/innovations/just-dont-go-thesequel/30693

*Farran, S. (2007, March 22). It hurts when you call me professor. Maclean's. Retrieved from http://www.macleans.ca/general/it-hurts-when-you-call-me-professor/ 
*Fullick, M. (2011, December 14). "My grief lies all within"-PhD students, depression \& attrition. University Affairs. Retrieved from http://www.universityaffairs.ca/ speculative-diction/my-grief-lies-all-within-phd-students-depression-attrition

*Fullick, M. (2012a, July 3). Punching for pedagogy. University Affairs. Retrieved from http://www.universityaffairs.ca/speculative-diction/punching-for-pedagogy/

*Fullick, M. (2012b, November 21). Filling in the gaps? Questions about goals and outcomes of a PhD education. University Affairs. Retrieved from http://www. universityaffairs.ca/speculative-diction/filling-in-the-gaps-questions-about-goals-andoutcomes-of-phd-education/

*Fullick, M. (2013a, January 2). Today's graduate students are not the elites of yesterday. The Globe and Mail. Retrieved from http://www.theglobeandmail.com/ news/national/education/todays-graduate-students-are-not-the-elites-of-yesterday/ article6808727/

*Fullick, M. (2013b, April 12). Who will hire all the PhDs? Not Canada's universities. The Globe and Mail. Retrieved from http://www.theglobeandmail.com/news/national/ education/who-will-hire-all-the-phds-not-canadas-universities/article10976412/

*Fullick, M. (2014, January 10). Thinking beyond ourselves: The "crisis" in academic work. University Affairs. Retrieved from http://www.universityaffairs.ca/speculativediction/thinking-beyond-ourselves-the-crisis-in-academic-work/

${ }^{*}$ Gillis, C. (2013, June 3). Are PhDs an academic dead zone? Maclean's. Retrieved from http://www.macleans.ca/society/life/an-academic-dead-zone/

Giroux, H. (2012). Education and the crisis of public values: Challenging the assault on teachers, students and public education. New York, NY: Peter Lang Publishing.

*Herbert-Copley, B. (2013, May 29). Few academic jobs, but Canada's need for PhDs grows. The Globe and Mail. Retrieved from http://www.theglobeandmail.com/ news/national/education/few-academic-jobs-but-canadas-need-for-phds-grows/ article12219592/

*Jaschik, S. (2010, January 4). No entry. Inside Higher Ed. Retrieved from http:// www.insidehighered.com/news/2010/01/04/nojobs

Kendall, G., \& Wickham, G. (1999). Using Foucault's methods. London, England: Sage Publications.

*Lewington, J. (2013, November 5). Is an MBA still worth it? The Globe and Mail. Retrieved from http://www.theglobeandmail.com/report-on-business/careers/businesseducation/is-an-mba-still-worth-it/article15276942/

Maistry, S. (2012). Confronting the neo-liberal brute: Reflections of a higher education middle manager. South African Journal of Higher Education, 26(3), 515-526.

Mills, S. (2003). Michel Foucault. New York, NY: Routledge.

Mills, S. (2004). Discourse. New York, NY: Routledge.

*Newhouse, M. (1999). Using graduate school strategically. Chronicle of Higher Education. Retrieved from http://chronicle.com/article/Using-Graduate-School/45663/ 
Nicoll, K., \& Harrison, R. (2003). Constructing the good teacher in higher education: The discursive work of standards. Studies in Continuing Education 25(1), 23-35.

Organisation for Economic Co-operation and Development. (1996). The knowledge based economy. Paris, France: OECD.

*Patton, S. (2012, December 6). MLA president offers a sobering critique of graduate education in the humanities. The Chronicle of Higher Education. Retrieved from http:// chronicle.com/article/A-Stark-Appraisal-of-Graduate/136171/

*Polk, J. (2014a, January 15). Transition Q\&A: Maren Wood. University Affairs. Retrieved from http://www.universityaffairs.ca/from-phd-to-life/

*Polk, J. (2014b, February 6). Transition Q\&A: Sarah-Louise Quinnell. University Affairs. Retrieved from http://www.universityaffairs.ca/from-phd-to-life/

Rose, M. (2012). Graduate student professional development: A survey with recommendations. Retrieved from http://www.sshrc-crsh.gc.ca/about-au_sujet/ publications/SSHRC_Report_Graduate_Students_Professional_Skills_March_2012_ eng.pdf

*Rybak, J. (2009, June 5). The PhD warning. Maclean's. Retrieved from http://www. macleans.ca/education/uniandcollege/the-phd-warning/

Saunders, D. N. (2010). Neoliberal ideology and public higher education in the United States. Journal for Critical Education Policy, 8(1), 42-77.

*Schirle, T. (2013, September 9). No need for universities to become job-specific trainers.

The Globe and Mail. Retrieved from http://www.theglobeandmail.com/report-on-

business/economy/economy-lab/no-need-for-universities-to-become-job-specificskills-trainers/article14185696/

*Skidmore, J. (2013, October 1). University is not about the subject, but about education. The Globe and Mail. Retrieved from http://www.theglobeandmail.com/news/national/ education/university-is-not-about-the-subject-but-about-education/article14613258/

Tamboukou, M., \& Ball, S. J. (2003). Genealogy and ethnography: Fruitful encounters or dangerous liaisons. In M. Tamboukou \& S. J. Ball (Eds.), Dangerous encounters: Genealogy and ethnography (pp. 1-36). New York, NY: Peter Lang.

*Tamburri, R. (2009, October 21). Why go to university? The Globe and Mail. Retrieved from http://www.theglobeandmail.com/news/national/education/why-go-touniversity/article4192831/?page $=$ all

*Tamburri, R. (2010, January 11). Give us the dirt on jobs. University Affairs. Retrieved from http://www.universityaffairs.ca/give-us-the-dirt-on-jobs.aspx

*Tamburri, R. (2013a, February 6). The PhD is in need of revision. University Affairs. Retrieved from http://www.universityaffairs.ca/the-phd-is-in-need-of-revision.aspx

*Tamburri, R. (2013b, November 25). Is a PhD a waste of time? University Affairs. Retrieved from http://www.universityaffairs.ca/margin-notes/is-a-phd-a-waste-oftime/ 
*Tamburri, R. (2014, March 19). A conversation with George Fallis. University Affairs. Retrieved from http://www.universityaffairs.ca/a-conversation-with-george-fallis.aspx

*Taylor, M. (2009, April 26). End the university as we know it. The New York Times. Retrieved from http://www.nytimes.com/2009/04/27/opinion/27taylor. $\mathrm{html}$ ?pagewanted=all\&_r=o

*Taylor, M. (2011). Reform the PhD system or close it down. Nature, 472, 259-260.

Titchkosky, T. (2007). Reading and writing disability differently: The textured life of embodiment. Toronto, ON: University of Toronto Press.

*Tremonti, A.M. (2014, January 27). The income gap between tenure faculty \& adjunct contract professors in Canadian universities [Radio broadcast]. In S. Higgins \& S. Grant (Producers), The Current. Toronto, ON: Canadian Broadcasting Corporation.

Vander Kloet, M. (2010). Cataloguing wilderness: Whiteness, masculinity and responsible citizenship in Canadian outdoor recreation texts. (Unpublished doctoral dissertation). University of Toronto, Toronto.

Vander Kloet, M., \& Aspenlieder, E. (2013). Educational development for responsible graduate students in the neoliberal university. Critical Studies in Education 54(3), 286298.

\section{Contact Information}

Erin Aspenlieder

Open Learning and Educational Support

University of Guelph

easpenli@uoguelph.ca

Erin Aspenlieder is an educational developer at the University of Guelph. She researches graduate student teaching and professional development, educational development and learning outcomes assessment.

Marie Vander Kloet is an educational consultant at McMaster University. Her areas of research include accessibility; equity and inclusion; graduate education and employment; neo-liberalism in higher education; and educational development. 
Appendix: Institutions and Courses Analyzed, 2012-2014*

\begin{tabular}{|c|c|c|c|}
\hline University & Location & Course code & Course title \\
\hline Brock University & $\begin{array}{l}\text { St. Catharines, } \\
\text { ON }\end{array}$ & GRST5No1 & $\begin{array}{l}\text { The Theory and Practice of } \\
\text { University Teaching }\end{array}$ \\
\hline Concordia University & Montreal, PQ & & $\begin{array}{l}\text { Seminar in University } \\
\text { Teaching for Graduate } \\
\text { Students }\end{array}$ \\
\hline Dalhousie University & Halifax, NS & CNLT $5000 / 1$ & $\begin{array}{l}\text { Learning and Teaching in } \\
\text { Higher Education }\end{array}$ \\
\hline McGill University & Montreal, PQ & EDPH689 & $\begin{array}{l}\text { Teaching and Learning in } \\
\text { Higher Education }\end{array}$ \\
\hline McMaster University & Hamilton, ON & EDU750 & $\begin{array}{l}\text { Principles and Practices of } \\
\text { University Teaching }\end{array}$ \\
\hline Memorial University & St. John's, NL & & $\begin{array}{l}\text { Teaching Skills } \\
\text { Enhancement Program }\end{array}$ \\
\hline Queen's University & Kingston, ON & SGS901 & $\begin{array}{l}\text { Teaching and Learning in } \\
\text { Higher Education }\end{array}$ \\
\hline \multirow[t]{2}{*}{ Ryerson University } & Toronto, ON & CILT 100 & $\begin{array}{l}\text { Learning and Teaching in } \\
\text { Higher Education } 1\end{array}$ \\
\hline & & CILT105 & $\begin{array}{l}\text { Learning and Teaching in } \\
\text { Higher Education } 2\end{array}$ \\
\hline Simon Fraser University & Burnaby, BC & & $\begin{array}{l}\text { University Teaching and } \\
\text { Learning: Principles and } \\
\text { Practices }\end{array}$ \\
\hline \multirow[t]{2}{*}{ University of Alberta } & Edmonton, $\mathrm{AB}$ & EXT532 & $\begin{array}{l}\text { Design and Development } \\
\text { of Learning, Teaching and } \\
\text { Assessment in Higher } \\
\text { Education }\end{array}$ \\
\hline & & EXT531 & $\begin{array}{l}\text { Philosophies, Theories and } \\
\text { Methods of Teaching and } \\
\text { Learning in Higher Educa- } \\
\text { tion }\end{array}$ \\
\hline University of Calgary & Calgary, AB & & $\begin{array}{l}\text { University Teaching Cer- } \\
\text { tificate }\end{array}$ \\
\hline University of Guelph & Guelph, ON & UNIV680o & $\begin{array}{l}\text { University Teaching: } \\
\text { Theory and Practice }\end{array}$ \\
\hline University of New Brunswick & Fredericton, NB & & $\begin{array}{l}\text { Diploma of University } \\
\text { Teaching }\end{array}$ \\
\hline University of Saskatchewan & Saskatoon, SK & GSR979 & $\begin{array}{l}\text { Introductory Instructional } \\
\text { Skills }\end{array}$ \\
\hline University of Toronto & Toronto, ON & THE5OO & $\begin{array}{l}\text { Teaching in Higher Educa- } \\
\text { tion }\end{array}$ \\
\hline
\end{tabular}




\begin{tabular}{|c|c|c|c|}
\hline University & Location & Course code & Course title \\
\hline University of Victoria & Victoria, BC & $\begin{array}{l}\text { ED-D614/Ao1 } \\
\text { (formerly } \\
\text { ED-D591A) }\end{array}$ & University Teaching \\
\hline \multirow[t]{3}{*}{ University of Windsor } & Windsor, ON & 05 80-591 (29) & $\begin{array}{l}\text { Theory and Philosophy of } \\
\text { Scholarly Teaching }\end{array}$ \\
\hline & & $0580-591(23)$ & $\begin{array}{l}\text { Course Design for Con- } \\
\text { structive Alignment }\end{array}$ \\
\hline & & $05-80-502(1)$ & $\begin{array}{l}\text { Learning-Centre Teach- } \\
\text { ing in Higher Education: } \\
\text { Principles and Practice }\end{array}$ \\
\hline Western University & London, ON & $\begin{array}{l}\text { Graduate } \\
\text { Studies 9500A }\end{array}$ & $\begin{array}{l}\text { The Theory and Practice of } \\
\text { University Teaching }\end{array}$ \\
\hline Wilfrid Laurier University & Waterloo, ON & & $\begin{array}{l}\text { Foundations in University } \\
\text { Teaching: } \\
\text { Doctoral Teaching Certifi- } \\
\text { cate }\end{array}$ \\
\hline
\end{tabular}

*All course syllabuses listed are for the years 2012-2014, with the exception of one from 2009. The 2009 syllabus was described as "current" by the institution. 